\title{
L-015＼cjkstart児童期における想起のコントロールの発達：“だいたい”と“正 確”の教示を用いて
}

\author{
講演者 : 佐々木真吾 (光塩学園女子短期大学) \\ 司会者：仲 真紀子 (北海道大学)
}

目撃証言や事情聴取をはじめとする記憶の想起過程に関する研究では, 想起者は記銘された情報をそ のまま報告するのではなく, 想起の目的や, 想起を求める人の期待に応じて想起内容をコントロールす ることが示されている。従来の想起研究では, 想起に影響を及ぼす外的要因（事後情報効果等）の検討 が主となっており，想起のコントロール過程という，内的要因は十分検討されてこなかった。とりわけ， コントロール能力の発達を扱う研究はわずかであり, こういった能力が, 他の認知機能と関わりながら, いかなる過程で発達するのかは未だ十分に解明されていない。本講演では，児童を対象に想起のコント ロールに関わる認知的要因とその発達過程を検討した 5 つの研究を報告する。“だいたいでよいので教え て下さい”, “できるだけ正確に教えて下さい”という異なる詳細さの報告を求める教示の効果を, 語用 論や，実行機能と関連づけながら報告する。

\section{L-016＼cjkstart在日コリアンに対するレイシズムの社会心理学的研究}

\author{
講演者：高史明 (神奈川大学) \\ 司会者：北村 英哉 (関西大学)
}

近年日本では, インターネット上を中心に, 在日コリアンを中心とする外国籍住民に対する排外主義 的な言説が盛んに流布されるようになり，深刻な社会的問題となっている。

本講演では, このような状況を理解し解決の糸口を探るために講演者が行なってきたこれまでの研究 を紹介し, 今後の研究の展望についても論じる。具体的には, (1) 米国で発展してきたレイシズムの理 論を援用し，在日コリアンに対するレイシズムを捉えるための枠組みを提示する。またそれに従って， （2）Twitterでの投稿を用いた計量テキスト分析によりインターネット上での差別的言説の実態を明ら かにし, さらに，（3）質問紙調査により明らかになった, レイシズムを強化し, あるいは弱める要因に ついて論じる。そして最後に，（4）今後必要とされる研究の枠組みを提示する。 